\title{
ANALISIS FAKTOR YANG MEMPENGARUHI PRODUKSI DAN PENDAPATAN PETANI GARAM DESA KUSAMBA KECAMATAN DAWAN KABUPATEN KLUNGKUNG
}

\author{
Gede Jaya Artawan ${ }^{1}$ \\ I Wayan Wenagama ${ }^{2}$
}

Fakultas Ekonomi dan Bisnis Universitas Udayana (Unud), Bali, Indonesia ${ }^{1,2}$

\begin{abstract}
One of the traditional agricultural commodities in Bali, especially in Kusamba Village, Dawan District, Klungkung Regency is salt, which is known as a source of livelihood in Kusamba Village. The purpose of this study was to analyze the factors that influence the production and income of salt farmers in Kusamba Village, Dawan District, Klungkung Regency. The data used in this study are primary data obtained by conducting interviews with 62 salt farmers in Kusamba Village. The data analysis technique used in this study is path analysis. The test results showed that the area of land, labor and capital had a positive and significant effect on the amount of salt production in Kusamba Village, Dawan District, Klungkung Regency. Land area, labor, capital and salt production have a positive and significant effect on the income of salt farmers in Kusamba Village, Dawan District, Klungkung Regency. Land area, labor, and capital have a positive effect on the income of salt farmers through salt production in Kusamba Village, Dawan District, Klungkung Regency.
\end{abstract}

keywords: land area; labor; capital; income,production.

\begin{abstract}
ABSTRAK
Salah satu komoditas pertanian tradisional yang ada di Bali khususnya di Desa Kusamba Kecamatan Dawan Kabupaten Klungkung adalah garam, yang dikenal sebagai salah satu sumber mata pencaharian masyarakat di Desa Kusamba. Tujuan dari penelitian ini adalah untuk menganalisis faktor-faktor yang mempengaruhi produksi dan pendapatan petani garam di Desa Kusamba Kecamatan Dawan Kabupaten Klungkung. Data yang dipergunakan dalam penelitian ini adalah data primer yang diperoleh dengan melakukan wawancara kepada 62 orang petani garam di Desa Kusamba. Teknik analisis data yang digunakan dalam penelitian ini adalah analisis path. Hasil uji menunjukkan luas lahan, tenaga kerja dan modal berpengaruh positif dan signifikan terhadap jumlah produksi garam di Desa Kusamba Kecamatan Dawan Kabupaten Klungkung. Luas lahan, tenaga kerja, modal dan produksi garam berpengaruh positif dan signifikan terhadap pendapatan petani garam di Desa Kusamba Kecamatan Dawan Kabupaten Klungkung. Luas lahan, tenaga kerja, dan modal berpengaruh positif terhadap pendapatan petani garam melalui produksi garam di Desa Kusamba Kecamatan Dawan Kabupaten Klungkung.
\end{abstract}

Kata kunci: luas lahan; tenaga kerja; modal; pendapatan; produksi. 


\section{PENDAHULUAN}

Indonesia merupakan negara agraris, mayoritas penduduknya bermata pencaharian di sektor pertanian, terlebih lagi Indonesia hanya mengalami 2 musim tiap tahunnya sehingga petani dapat berusaha tani kapan saja. Kelebihan inilah yang tidak dimiliki oleh negara di belahan bumi lainnya, seperti negara- negara di Benua Eropa antara lain Amerika, Rusia, dan Spanyol, negara- negara tersebut hanya mengalami 4 musim, sehingga tak heran jika Indonesia disebut sebagai negara agraris. Pertanian merupakan sektor yang masih memegang peranan dalam peningkatan perekonomian nasional. Permintaan yang terus meningkat berupa kebutuhan pangan dan yang lainnya menyebabkan para petani meningkatkan produksinya demi memenuhi semua permintaan pasar (Antara \& Yono, 2013).

Pertanian menjadi sektor utama penggerak pertumbuhan ekonomi sehingga perannya sangat sentral bagi perkonomian Indonesia (Kasryno, 2000). Salah satu sektor yang memiliki peranan penting dalam ekonomi sebuah negara adalah pertanian. Tidak hanya pada perekonomian, sektor pertanian juga berperan dalam pembangunan nasional guna untuk mencapai ekonomi yang berkelanjutan (Agustarita \& Sudirman, 2015). Keberhasilan pembangunan pertanian ditentukan oleh keberhasilan tumbuhnya lingkungan komoditas pertanian tanaman pangan, holtikultura, perkebunan, perikanan, dan peternakan yang masih kental dalam kehidupan masyarakat disetiap provinsi yang tersebar di Indonesia (Ardika, 2017).

Pengembangan sektor pertanian di Indonesia dianggap menjadi yang terpenting dari keseluruhan pembangunan ekonomi, beberapa alasan yang 
mendasari pentingnya pertanian di Indonesia: (1) potensi sumberdayanya yang besar dan beragam, (2) Kontribusi terhadap pendapatan nasional cukup besar, (3) Jumlah penduduk yang menggantungkan hidupnya pada sektor ini sangat banyak dan (4) menjadi basis pertumbuhan ekonomi di pedesaan (Tri Astari \& Djinar Setiawina, 2016). Perkembangan ekonomi khususnya sektor pertanian adalah salah satu kegiatan untuk meningkatkan kesejahteraan masyarakat dalam arti tingkat hidup yang lebih maju maupun taraf hidup yang lebih bermutu, sehinga diusahakan jika semakin besar kegiatan ekonomi khususnya sektor pertanian maka semakin luas lapangan kerja produktif bagi masyarakat (Berihun \& Bihon (2014).

Sektor pertanian dapat dibagi menjadi beberapa subsektor yaitu subsektor pangan dan hortikultura, perkebunan, peternakan, perikanan, dan kehutanan serta jasa pertanian. Meskipun kini pertanian mulai ditinggalkan karena banyak petani yang melakukan urbanisasi untuk beralih ke sektor industri (Sharma, 2007). Peningkatan produksi dalam sub sektor pertanian harus diutamakan, karena sektor pertanian merupakan sektor yang paling sentral bagi negara berkembang seperti Indonesia (Al-Haboby et al, 2016). Sektor pertanian di sebagian besar wilayah Indonesia menjadi prioritas utama dalam penunjang perekonomian, sama seperti provinsi lain yang ada di Indonesia.

Bali merupakan provinsi yang masih mengandalkan pertanian sebagai pekerjaan utama dan sumber pendapatan masyarakatnya (Ardika \& Gede, 2017). Dengan adanya sektor pertanian yang mencakup komponen sosial, ekonomi, lingkungan, dan kelembagaan dalam bidang pertanian diharapkan dapat menjadi 
penggerak sektor-sektor ekonomi dalam pembangunan ekonomi pedesaan (Jelocnik, 2011). Bahkan dapat dikatakan bahwa tidaklah mungkin masyarakat pedesaan Bali dapat menjalankan kehidupannya tanpa pertanian tradisional. Hingga saat ini sektor pertanian tradisional masih menjadi andalan kehidupan masyarakat pedesaan (Dharma Saputra \& Wenagama, 2019). Salah satu komoditas pertanian tradisional yang dikembangkan di Bali adalah garam. Garam memiliki peran yang dibutukan dalam makanan sehari-hari untuk konsumsi. Rasa asin dari garam tidak dapat digantikan oleh komoditas lain (Izzaty \& Sony, 2011). Bali memiliki 9 Kabupaten/Kota yang memproduksi garam. Dapat dilihat pada tabel 1 merupakan produksi garam menurut kabupaten atau kota di provinsi Bali tahun 2014-2018.

Tabel 1.

Produksi Garam menurut Kabupaten atau Kota di Provinsi Bali Tahun2014-2018.

\begin{tabular}{lccccc}
\hline \multirow{2}{*}{ Kabupaten /Kota } & \multicolumn{5}{c}{ Jumlah Produksi Garam (Ton) } \\
\cline { 2 - 6 } & $\mathbf{2 0 1 4}$ & $\mathbf{2 0 1 5}$ & $\mathbf{2 0 1 6}$ & $\mathbf{2 0 1 7}$ & $\mathbf{2 0 1 8}$ \\
\hline Buleleng & 3.421 & 2.307 & 2.187 & 1.679 & 1.554 \\
Jembrana & 803 & 920 & 850 & 1.200 & 1.005 \\
Karangasem & 780 & 820 & 1.330 & 1.438 & 976 \\
Tabanan & 9 & 8 & 8 & 2 & 3 \\
Bangli & - & - & - & - & - \\
Badung & 435 & 308 & 280 & 232 & 221 \\
Gianyar & 584 & 600 & 487 & 587 & 572 \\
Klungkung & 4.618 & 3.144 & 2.243 & 1.827 & 1.672 \\
Denpasar & 550 & 432 & 438 & 583 & 600 \\
\hline Sumbryyyyy
\end{tabular}

Sumber: Dinas Kelautan dan Perikanan Provinsi Bali, 2018

Tabel 1 menunjukkan data produksi garam menurut kabupaten atau kota di Provinsi Bali tahun 2014-2018. Dari sembilan kabupaten atau kota yang berada di Provinsi Bali, terlihat bahwa Kabupaten Klungkung sebagai penyumbang garam paling besar daripada kabupaten atau kota lainnya. Kabupaten Klungkung 
sebagian penduduknya bermata pencaharian sebagai petani garam dan memiliki potensi dalam pengembangan usaha garam rakyat. Khususnya di Kecamatan Dawan. Untuk lebih terperinci dapat dilihat pada Tabel 2 produksi garam menurut kecamatan di Kabupaten Klungkung.

Tabel 2.

Produksi Garam Menurut Kecamatan Di Kabupaten Klungkung

\begin{tabular}{lccccc}
\hline \multirow{2}{*}{ Kecamatan } & \multicolumn{5}{c}{ Jumlah Produksi Garam (Ton) } \\
\cline { 2 - 6 } & $\mathbf{2 0 1 4}$ & $\mathbf{2 0 1 5}$ & $\mathbf{2 0 1 6}$ & $\mathbf{2 0 1 7}$ & $\mathbf{2 0 1 8}$ \\
\hline Banjarangkan & - & - & - & - & - \\
Dawan & 4.618 & 3.144 & 2.243 & 1.827 & 1.672 \\
Nusa Penida & - & - & - & - & - \\
\hline Sumber: Kantor Came
\end{tabular}

Sumber: Kantor Camat Dawan, 2018

Tabel 2 menunjukkan data produksi garam menurut kecamatan di Kabupaten Klungkung. Terlihat bahwa dari tiga kecamatan yang berada di Kabupaten Klungkung hanya Kecamatan Dawan saja sebagai penghasil garam. Namun jumlah produksinya mengalami penurunan setiap tahunnya. Pada Kecamatan Banjarangkan, sektor yang dikembangkan di kecamatan tersebut adalah perkebunan. Pada Kecamatan Nusa Penida, mata pencaharian utama masyarakat disana adalah petani rumput laut. Produksi garam pada Kecamatan Dawan terdapat di dua desa yaitu Desa Pesinggahan dan Desa Kusamba. Pada Tabel 3 merupakan data produksi garam menurut Desa di Kecamatan Dawan Kabupaten Klungkung.

Tabel 3.

Produksi Garam Menurut Desa di Kecamatan Dawan Kabupaten Klungkung

\begin{tabular}{lccccc}
\hline \multirow{2}{*}{ Desa } & \multicolumn{5}{c}{ Jumlah Produksi Garam (Ton) } \\
\cline { 2 - 6 } & $\mathbf{2 0 1 4}$ & $\mathbf{2 0 1 5}$ & $\mathbf{2 0 1 6}$ & $\mathbf{2 0 1 7}$ & $\mathbf{2 0 1 8}$ \\
\hline Pesinggahan & 1,975 & 1,458 & 881 & 769 & 675 \\
Kusamba & 2,643 & 1,686 & 1442 & 1058 & 997 \\
\hline Sumber: Kantor Desa Pesinggahan dan Kusamba Kecamatan Dawan, 2018
\end{tabular}


Tabel 3 menunjukkan produksi garam menurut desa di Kecamatan Dawan Kabupaten Klungkung yang memiliki jumlah produksi garam yang berbeda-beda dan memiliki kontribusi dalam hasil garam. Desa Kusamba memiliki produksi garam yang paling tinggi di tiap tahunnya namun selalu mengalami penurunan dan Pesinggahan yang hasil produksinya paling rendah, hal ini dikarenakan beberapa faktor yaitu luas lahan yang semakin mengikis akibat abrasi pantai, jumlah tenaga kerja yang berkurang dikarenakan banyaknya para petani garam yang beralih ke pekerjaan lain dan modal yang terbatas. Jumlah produksi tersebut akan mengakibatkan pendapatan petani garam yang berbeda-beda. Jika produksi garam tinggi, maka penghasilan petani garam akan meningkat. Sebaliknya, jika produksi petani garam rendah,tingkat penghasilan petani garam akan menurun. Adapun jumlah petani garam yang berada di Kecamatan Dawan Kabupaten Klungkung yang bersumber dari Kantor Desa Pesinggahan dan Kusamba Kecamatan Dawan 2018, menunjukkan jumlah petani garam yang berada di Desa Kusamba pada tahun 2018 berjumlah 165 orang. Di Desa Kusamba ini memiliki kelompok usaha bersama yang terbagi dalam lima kelompok yaitu Amerta Segara sebanyak 34 orang, Sarining segara sebanyak 37 orang, Segara mukti sebanyak 31 orang, Kusuma Bahari sebanyak 33 orang dan Windu segara sebanyak 30 orang. Dengan adanya kelompok usaha bersama ini diharapkan mampu membantu meningkatkan produksi garam dan dapat meningkatkan pendapatan dari para petani garam tersebut. Pendapatan yang diperoleh nantinya dapat digunakan sebagai alat untuk memenuhi kebutuhan. Terpenuhinya kebutuhan yang 
diinginkan oleh seseorang membuat dirinya semakin dekat untuk mencapai kesejahteraan (Hae-Young, 2013).

Kelompok usaha bersama ini dapat memberikan keuntungan diantaranya: (1) memperbesar kemampuan sumberdaya dan meningkatkan skala usaha ekonomi kolektif yang dimiliki masyarakat, (2) meningkatkan posisi tawar kolektif dalam mengakses modal, pasar, teknologi, dan kebijakan, (3) mengembangkan kemampuan koordinasi dan kerja sama kemitraan dalam pengelolaan kegiatan ekonomi kolektif untuk mendukung dinamika ekonomi kawasan, dan (4) memudahkan pengontrolan terhadap perjalanan ekonomi bersama (Michael Todaro, 2006 ).

Desa Kusamba sebagian besar penduduknya sebagai petani garam yang dimana mengandalkan penghasilan dari hasil garam tersebut maka ada beberapa faktor yang mempengaruhi produksi dan pendapatan petani garam di desa Kusamba yaitu faktor luas lahan, tenaga kerja dan modal.

Luas Lahan merupakan faktor produksi terpenting dalam pertanian karena merupakan tempat dimana usaha tani dapat dilakukan guna menghasilkan produksi (Mubyarto, 1989:89). Luas penguasaan lahan pertanian merupakan sesuatu yang sangat penting dalam proses produksi ataupun usaha tani dan usaha pertanian. Dalam usaha tani misalnya pemilikan atau penguasaan lahan sempit sudah pasti kurang efisien dibanding lahan yang lebih luas. Menurut Assis et al (2014) bahwa luas lahan merupakan satu-satunya faktor yang memiliki efek yang signifikan terhadap pendapatan bulanan pada petani, jadi jika luas lahan meningkat maka pendapatan petani akan meningkat. Luas lahan merupakan hal 
yang paling utama dalam usaha tani, dimana semakin luas lahan maka semakin besar pula jumlah produksi yang dihasilkan oleh petani (Manik, 2014). Besar kecilnya hasil produksi dari usaha tani dipengaruhi oleh luas sempitnya lahan yang digunakan (Bengen, 2004). Ukuran lahan dapat dinyatakan dengan hektar (ha) atau are (Rachman, 2011).

Menurut Mulyadi (2003:59), tenaga kerja adalah penduduk yang mampu bekerja dalam proses produksi barang dan jasa. Tenaga kerja menjadi komponen penting dalam sebuah usaha yang masih tradisional karena mereka yang akan menjalankan produksi dari sebuah usaha. Menurut Suprihanto (2003:25) menyatakan bahwa tenaga kerja adalah sebagian dari keseluruhan penduduk yang secara potensial dapat menghasilkan barang dan jasa. Tenaga kerja merupakan salah satu faktor produksi yang sangat memegang peranan penting dalam produksi. Faktor tenaga kerja merupakan faktor produksi yang penting untuk diperhatikan dalam proses produksi dalam jumlah yang cukup, bukan saja dilihat dari tersedianya lapangan kerja tetapi juga kualitas dan macam tenaga kerja (Machfudz, 2007: 97). Setiap proses produksi harus disediakan tenaga kerja yang cukup memadai, jumlah tenaga kerja yang digunakan harus disesuaikan dengan kebutuhan sampai tingkat tertentu sehingga optimal (Akbar, 2017).Penggunaan tenaga kerja akan intensif apabila tenaga kerja dapat memberikan manfaat yang optimal dalam proses produksi (Miftakhuriza, 2011). Semakin banyak tenaga kerja yang digunakan maka semakin banyak pula output yang dapat dihasilkan dalam produksi (Mankiw, 2000: 46). Tujuan penelitian:1). Untuk menganalisis pengaruh luas lahan, tenaga kerja dan modal secara langsung terhadap produksi 
petani garam di Desa Kusamba. 2). Untuk menganalisis pengaruh luas lahan, tenaga kerja, modal dan produksi garam secara langsung terhadap pendapatan petani garam di Desa Kusamba. 3). Untuk menganalisis luas lahan, tenaga kerja dan modal secara tidak langsung terhadap pendapatan petani garam melalui produksi garam di Desa Kusamba.

\section{METODE PENELITIAN}

Penelitian ini termasuk dalam jenis penelitian kuantitatif. Penelitian ini dilakukan di di Desa Kusamba Kecamatan Dawan Kabupaten Klungkung. Alasan pengambilan lokasi penelitian di Desa Kusamba karena lokasi tersebut sebagi penghasil garam dan sebagian besar mata pencarian masyarakat adalah petani garam. Objek penelitian ini memfokuskan pada lima variabel yaitu luas lahan, tenaga kerja, modal, produksi dan pendapatan petani garam di Desa Kusamba Kecamatan Dawan Kabupaten Klungkung. Variabel terikat dalam penelitian ini adalah pendapatan petani garam $\left(\mathrm{Y}_{2}\right)$. Varibel intervening dalam penelitian ini adalah produksi garam $\left(\mathrm{Y}_{1}\right)$. variabel bebas dalam penelitian ini adalah luas lahan $\left(\mathrm{X}_{1}\right)$, tenaga kerja $\left(\mathrm{X}_{2}\right)$ dan modal $\left(\mathrm{X}_{3}\right)$.

Data kuantitatif yang digunakan dalam penelitian adalah daftar pertanyaan yang terdapat di kuisioner penelitian mengenai variabel luas lahan, tenaga kerja, modal, produksi dan pendapatan petani garam di Desa Kusamba Kecamatan Dawan Kabupaten Klungkung. Data kualitatif dalam penelitian ini adalah berupa keterangan dan informasi untuk melengkapi interpretasi data tentang pendapatan, produksi, luas lahan, tenaga kerja, dan modal berdasarkan penelitian sebelumnya. 
Dalam penelitian ini data primer adalah data yang diperoleh dari kuisioner, meliputi daftar pertanyaan tersebut menyangkut tentang variabel luas lahan, tenaga kerja, modal, pendapatan dan hasi produksi petani garam di Desa Kusamba Kecamatan Dawan Kabupaten Klungkung. Dalam penelitian ini data sekunder meliputi data laporan hasil penelitian dan laporan gambaran umum lokasi penelitian.

Untuk memperoleh data yang diperlukan dalam penelitian ini digunakan beberapa teknik pengumpulan data adalah observasi adalah teknik pengumpulan data yang dilakukan peneliti dengan cara melakukan pengamatan langsung atau terjun langsung untuk mengetahui dan melihat segala aktivitas yang dilakukan oleh petani garam dan Wawancara terstruktur adalah teknik pengumpulan data dengan menggunakan pertanyaan sekitar kuisioner yang berkaitan dengan variabel-variabel yang diperlukan untuk menjawab permasalahan, yaitu tentang luas lahan, tenaga kerja, modal, produksi dan pendapatan yang digunakan oleh para petani garam. Populasi dalam penelitian ini adalah petani garam yang berada di Desa Kusamba, Kecamatan Dawan, Kabupaten Klungkung sebanyak 165 petani garam yang terbagi dalam kelompok usaha bersama.

Metode penentuan sampel yaitu menggunakan teknik probability sampling dengan metode proportionate stratified random sampling dan dilakukan dengan cara undian pada pengambilan sampel berdasarkan pendekatan slovin. Sampel yang digunakan dalam penelitian ini adalah kelompok petani garam di Desa Kusamba, Kecamatan Dawan, Kabupaten Klungkung sebanyak 62 petani garam. Dari penelitian yang dilakukan sebelumnya, Menurut Krishna et al 
(2014) faktor luas lahan berpengaruh positif terhadap produksi. Pada penelitian yang dilakukan oleh (Gouse, 2006), (Saragih, 2013), (Risandewi, 2013), dan (Shan \& Anran, 2015) mendapatkan hasil bahwa faktor luas lahan berpengaruh positif terhadap produksi. Penelitian yang dilakukan oleh (Arimbawa, 2017) menyatakan bahwa luas lahan berpengaruh positif dan signifikan terhadap Pendapatan Petani Padi di Kecamatan Mengwi. (Bintang Suryaniti, 2018) menyatakan bahwa luas lahan dan produksi secara langsung berpengaruh positif dan signifikan terhadap pendapatan petani. (Riska Aryawati, 2018) menyatakan Luas lahan berpengaruh positif dan signifikan terhadap pendapatan petani di Provinsi Bali.

Nugroho \& Muchamad (2014) menyatakan bahwa tenaga kerja berpengaruh positif terhadap produksi susu Kabupaten Boyolali. Selain itu menurut penelitian yang dilakukan oleh $\mathrm{Ng}$ 'ombe et al (2014) tenaga kerja merupakan faktor produksi yang paling berpengaruh terhadap hasil produksi. Luas lahan, tenaga kerja berpengaruh positif dan signifikan terhadap produksi usaha tani jeruk di Kecamatan Tembuku Kabupaten Bangli (Dinda,2019). I Putu Danendra Putra \& I Wayan Sudirman (2015) yang menyatakan bahwa variabel tenaga kerja berpengaruh positif dan signifikan terhadap pendapatan pada usaha warung makan di Kecamatan Abiansemal.

Sri Yuniartini (2013) menyatakan bahwa modal mempunyai pengaruh positif dan signifikan terhadap hasil produksi pada industri kerajinan ukiran kayu di Kecamatan Ubud, Kabupaten Gianyar. Penelitian yang dilakukan (Dinda,2019) menyatakan bahwa modal berpengaruh positif dan signifikan 
terhadap produksi usaha tani jeruk di Kecamatan Tembuku Kabupaten Bangli. Deviana (2015) menyatakan modal berpengaruh positif dan signifikan terhadap produksi industri kerajinan kayu di Kecamatan Abiansemal. Setyaningsih Sri Utami \& Edi Wibowo (2013) menyatakan bahwa modal berpengaruh positif terhadap pendapatan pedagang di pasar Klithikan Notoharjo Surakarta. Hastina (2013) menyatakan bahwa modal pengusaha berpengaruh positif terhadap pendapatan pengusaha marning jagung.

Penelitian yang dilakukan oleh Dwiky Wirawan (2019) modal dan tenaga kerja berpengaruh positif dan signifikan terhadap produksi. Modal, tenaga kerja dan produksi berpengaruh positif dan signifikan terhadap pendapatan. Produksi merupakan variabel intervening yang memediasi pengaruh variabel modal terhadap pendapatan dan produksi juga sebagai variabel intervening yang memediasi pengaruh variabel tenaga kerja terhadap pendapatan. Penelitian yang dilakukan oleh Riska Aryawati (2018) menyatakan bahwa Produksi pertanian berpengaruh positif dan signifikan terhadap pendapatan petani di Provinsi Bali.

Hasil penelitian Ratih Wulandari (2017) menyatakan bahwa modal berpengaruh positif terhadap pendapatan, tenaga kerja berpengaruh positif dan signifikan terhadap pendapatan. Hasil penelitian Santi Virnayanti (2018) menunjukkan bahwa tenaga kerja dan modal berpengaruh positif terhadap produksi pengrajin kayu. Sehingga berdasarkan pemaparan diatas, adapun kerangka konseptual yang dapat disajikan pada Gambar 1. 


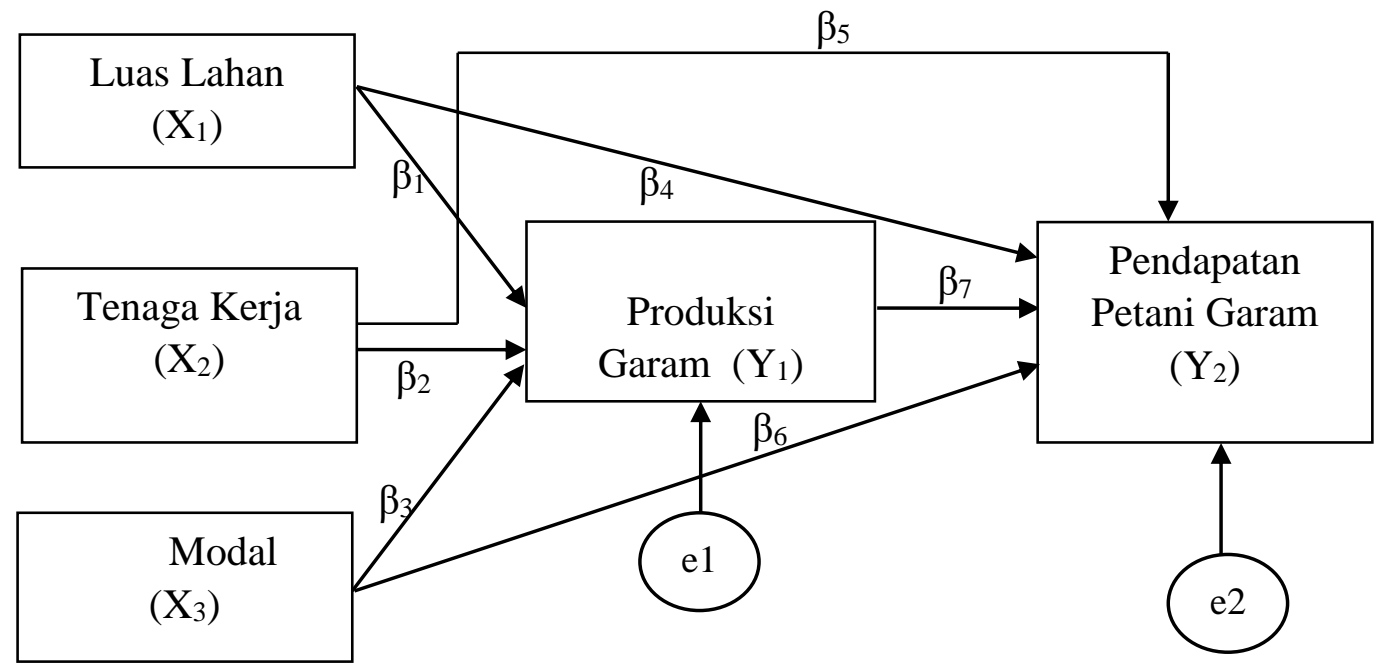

Gambar 1.

Analisis Faktor-Faktor Yang Mempengaruhi Produksi dan Pendapatan Petani Garam di Desa Kusamba Kecmatan Dawan Kabupaten Klungkung.

Berdasarkan kerangka konseptual pada Gambar 1 dapat dibuat persamaan regresi yang digunakan dalam penelitian ini sebagai berikut:

Persamaan Substruktur I

$Y_{1}=\beta_{1} X_{1}+\beta_{2} X_{2}+\beta_{3} X_{3}+e_{1}$

Persamaan Substruktur II

$\mathrm{Y}_{2}=\beta_{4} \mathrm{X}_{1}+\beta_{5} \mathrm{X}_{2}+\beta_{6} \mathrm{X}_{3}+\beta_{7} \mathrm{Y}_{1}+\mathrm{e}_{2}$

Berdasarkan Gambar 1 dapat dilihat anak panah $\beta_{1}$ menunjukkan pengaruh variabel $X_{1}$ terhadap $Y_{1}$. Lalu anak panah $\beta_{4}$ menunjukkan pengaruh variabel $X_{1}$ terhadap $Y_{2}$. Anak panah $\beta_{2}$ menunjukkan pengaruh variabel $\mathrm{X}_{2}$ terhadap $\mathrm{Y}_{1}$. Lalu anak panah $\beta_{5}$ menunjukan pengaruh variabel $X_{2}$ terhadap $Y_{2}$. Anak panah $\beta_{3}$ menunjukkan pengaruh variabel $\mathrm{X}_{3}$ terhadap $\mathrm{Y}_{1}$. Lalu anak panah $\beta_{6}$ menunjukan 
pengaruh variabel $X_{3}$ terhadap $Y_{2}$. Kemudian anak panah $\beta_{7}$ menunjukkan pengaruh variabel $\mathrm{Y}_{1}$ terhadap $\mathrm{Y}_{2}$.

Tabel 4.

Pengaruh Langsung, Tidak Langsung dan Pengaruh Total Variabel Luas lahan, Tenaga kerja, Modal, Produksi garam dan Pendapatan petani garam di Desa Kusamba,Kecamatan Dawan, Kabupaten Klungkung

\begin{tabular}{clcc}
\hline $\begin{array}{c}\text { Hubungan } \\
\text { Variabel }\end{array}$ & Langsung & $\begin{array}{c}\text { Tidak } \\
\text { Langsung } \\
\left.\text { (melalui } \mathrm{Y}_{1}\right)\end{array}$ & Total \\
\cline { 2 - 3 } & $\beta_{1}$ & - & $\beta_{1}$ \\
$\mathrm{X}_{1} \rightarrow \mathrm{Y}_{1}$ & $\beta_{4}$ & $\beta_{8}=\left(\beta_{1} x \beta_{7}\right)$ & $\beta_{4}+\left(\beta_{1} x \beta_{7}\right)$ \\
$\mathrm{X}_{1} \rightarrow \mathrm{Y}_{2}$ & $\beta_{2}$ & - & $\beta_{2}$ \\
$\mathrm{X}_{2} \rightarrow \mathrm{Y}_{1}$ & $\beta_{5}$ & $\beta_{9}=\left(\beta_{2} x \beta_{7}\right)$ & $\beta_{5}+\left(\beta_{2} x \beta_{7}\right)$ \\
$\mathrm{X}_{2} \rightarrow \mathrm{Y}_{2}$ & $\beta_{3}$ & - & $\beta_{3}$ \\
$\mathrm{X}_{3} \rightarrow \mathrm{Y}_{1}$ & $\beta_{6}$ & $\beta_{10}=\left(\beta_{3} x \beta_{7}\right)$ & $\beta_{6}+\left(\beta_{3} x \beta_{7}\right)$ \\
$\mathrm{X}_{3} \rightarrow \mathrm{Y}_{2}$ & $\beta_{7}$ & - & $\beta_{7}$ \\
$\mathrm{Y}_{1} \rightarrow \mathrm{Y}_{2}$ & $\beta_{7}$ & & \\
\hline
\end{tabular}

\section{HASIL DAN PEMBAHASAN}

Analisis jalur merupakan perluasan penerapan analisis regresi linear berganda untuk memprediksi hubungan sebab akibat antarvariabel (model kausal) yang telah ditetapkan sebelumnya berdasarkan teori. Dalam analisis jalur, terdapat variabel yang berperan ganda yang disebut dengan variabel mediasi (intervening). Pengujian persamaan satu digunakan untuk mengetahui pengaruh secara langsung antara variabel luas lahan, tenaga kerja dan modal terhadap produksi petani garam yang diolah dengan program bantu yaitu SPSS maka uji regresi disajikan dalam Tabel 5. 
Pengujian persamaan satu digunakan untuk mengetahui pengaruh secara langsung antara variabel luas lahan, tenaga kerja dan modal terhadap produksi petani garam adalah sebagai berikut.

Tabel 5.

Hasil Uji Regresi Luas lahan, Tenaga Kerja dan Modal Terhadap Produksi Petani Garam

\begin{tabular}{|c|c|c|c|c|c|c|}
\hline \multicolumn{7}{|c|}{ Coefficients $^{\mathbf{a}}$} \\
\hline \multirow[b]{2}{*}{ Model } & & \multicolumn{2}{|c|}{$\begin{array}{c}\text { Unstandardized } \\
\text { Coefficients }\end{array}$} & \multirow{2}{*}{$\begin{array}{c}\begin{array}{c}\text { Standardized } \\
\text { Coefficients }\end{array} \\
\text { Beta }\end{array}$} & \multirow[t]{2}{*}{$\mathbf{t}$} & \multirow{2}{*}{ Sig. } \\
\hline & & B & Std. Error & & & \\
\hline \multirow[t]{4}{*}{1} & (Constant) & 5,250 & ,366 & & 14,343 & ,000 \\
\hline & LnX1 & ,287 & , 120 & ,372 & 2,385 & ,020 \\
\hline & LnX2 & , 152 & ,065 & ,207 & 2,317 & ,024 \\
\hline & LnX3 & ,262 & , 111 & ,369 & 2,352 & ,022 \\
\hline
\end{tabular}

a. Dependent Variable: LnY1

Sumber : Data diolah, 2019

Tabel 5 menunjukkan pengujian pengaruh langsung luas lahan terhadap produksi garam menunjukkan bahwa nilai standardized coefficient beta sebesar 0,372 dan nilai sig. sebesar $0,020<0,05$ ini memiliki arti bahwa $\mathrm{H}_{0}$ ditolak dan $\mathrm{H}_{1}$ diterima, artinya luas lahan $\left(\mathrm{X}_{1}\right)$ berpengaruh positif dan signifikan terhadap produksi garam $\left(\mathrm{Y}_{1}\right)$. Hal ini berarti bahwa setiap peningkatan luas lahan sebesar 1 persen dengan harapan variabel lain konstan, maka akan menyebabkan peningkatan sebesar 0,372 persen pada produksi garam Di Desa Kusamba. Hasil penelitian ini didukung oleh (Dinda,2019) menyatakan bahwa luas lahan berpengaruh positif dan signifikan terhadap produksi. Luas lahan pertanian merupakan sesuatu yang sangat penting dalam proses produksi ataupun usaha tani. Lahan pertanian adalah hal yang paling utama dalam usaha tani, dimana semakin luas lahan maka semakin besar jumlah produksi yang mampu dihasilkan 
oleh petani (Arimbawa, 2017).

Pengaruh langsung tenaga kerja terhadap produksi garam menunjukkan bahwa nilai standardized coefficient beta sebesar 0,207 dan nilai sig. sebesar $0,024<0,05$ ini memiliki arti bahwa $\mathrm{H}_{0}$ ditolak dan $\mathrm{H}_{1}$ diterima, artinya tenaga kerja $\left(\mathrm{X}_{2}\right)$ berpengaruh positif dan signifikan terhadap produksi garam $\left(\mathrm{Y}_{1}\right)$. Hal ini berarti bahwa setiap peningkatan tenaga kerja sebesar 1 persen dengan harapan variabel lain konstan, maka akan menyebabkan peningkatan sebesar 0,207 persen pada produksi garam Di Desa Kusamba. Hasil penelitian ini didukung oleh Nugroho dan Muchamad (2014), dalam penelitian mereka yang berjudul "Pengaruh Modal, Tenaga Kerja dan Teknologi Terhadap Hasil Produksi Susu Kabupaten Boyolali” disimpulkan bahwa variabel tenaga kerja berpengaruh positif dan signifikan terhadap produksi susu Kabupaten Boyolali. Selain itu menurut penelitian yang dilakukan oleh Ng'ombe et al (2014), tenaga kerja merupakan faktor produksi yang paling berpengaruh terhadap hasil produksi.

Pengaruh langsung modal terhadap produksi garam menunjukkan bahwa nilai standardized coefficient beta sebesar 0,369 dan nilai sig. sebesar 0,022 < 0,05 ini memiliki arti bahwa $\mathrm{H}_{0}$ ditolak dan $\mathrm{H}_{1}$ diterima, artinya modal $\left(\mathrm{X}_{3}\right)$ berpengaruh positif dan signifikan terhadap produksi garam $\left(\mathrm{Y}_{1}\right)$. Hal ini berarti bahwa setiap peningkatan modal sebesar 1 persen dengan harapan variabel lain konstan, maka akan menyebabkan peningkatan sebesar 0,369 persen pada produksi garam Di Desa Kusamba. Modal memiliki peran penting dalam proses produksi, sehingga semakin besar modal yang digunakan dalam proses produksi 
maka akan lebih produktif dan begitu juga sebaliknya. Hasil penelitian ini didukung oleh penelitian Ni Putu Sri Yuniartini (2013) dimana hasil penelitiaanya, variabel modal mempunyai pengaruh positif dan signifikan terhadap hasil produksi pada industri kerajinan ukiran kayu di Kecamatan Ubud, Kabupaten Gianyar. Hasil penelitian ini juga didukung oleh Cahya Ningsih (2015) dimana modal memiliki pengaruh positif dan signifikan terhadap nilai produksi pada industri kerajinan perak. Hasil Penelitian dari Deviana (2015) juga menyatakan bahwa modal berpengaruh positif dan signifikan terhadap produksi industri kerajinan kayu di Kecamatan Abiansemal.

Pengujian pengaruh tidak langsung atau yang sering disebut Uji Sobel merupakan cara untuk menguji kekuatan pengaruh tidak langsung antar variabel independent $(\mathrm{X})$ terhadap variabel dependent $\left(\mathrm{Y}_{2}\right)$ melalui variabel intervening $\left(\mathrm{Y}_{1}\right)$. Pengujian persamaan dua dilakukan untuk melihat pengaruh luas lahan, tenaga kerja, modal dan produksi garam terhadap pendapatan petani garam adalah sebagai berikut.

Tabel 6.

Hasil Uji Regresi Luas lahan, Tenaga Kerja, Modal dan Produksi Garam Terhadap Pendapatan Petani Garam

\begin{tabular}{|c|c|c|c|c|c|c|}
\hline \multicolumn{7}{|c|}{ Coefficients $^{\mathrm{a}}$} \\
\hline \multirow{2}{*}{\multicolumn{2}{|c|}{ Model }} & \multicolumn{2}{|c|}{$\begin{array}{l}\text { Unstandardized } \\
\text { Coefficients }\end{array}$} & \multirow{2}{*}{$\begin{array}{c}\begin{array}{c}\text { Standardized } \\
\text { Coefficients }\end{array} \\
\text { Beta }\end{array}$} & \multirow[b]{2}{*}{$\mathbf{t}$} & \multirow[b]{2}{*}{ Sig. } \\
\hline & & B & Std. Error & & & \\
\hline \multirow[t]{5}{*}{1} & (Constant) &,- 760 & ,496 & & $-1,534$ &, 131 \\
\hline & LnX1 & ,239 &, 080 & ,312 & 2,989 &, 004 \\
\hline & $\operatorname{LnX} 2$ & , 134 & ,043 &, 184 & 3,072 &, 003 \\
\hline & LnX3 & , 188 & 074 & ,267 & 2,545 & ,014 \\
\hline & LnY1 &, 262 &, 063 & ,264 & 3,140 &, 003 \\
\hline
\end{tabular}

a. Dependent Variable: LnY2

Sumber: Data diolah, 2019 
Tabel 6 menunjukkan pengaruh langsung luas lahan terhadap pendapatan petani garam menunjukkan bahwa nilai standardized coefficient beta sebesar 0,312 dan nilai sig. sebesar $0,004<0,05$ ini memiliki arti bahwa $\mathrm{H}_{0}$ ditolak dan $\mathrm{H}_{1}$ diterima, artinya luas lahan $\left(\mathrm{X}_{1}\right)$ berpengaruh positif dan signifikan terhadap pendapatan petani garam $\left(\mathrm{Y}_{2}\right)$. Hal ini berarti bahwa setiap peningkatan luas lahan sebesar 1 persen dengan harapan variabel lain konstan, maka akan menyebabkan peningkatan sebesar 0,312 persen pada pendapatan petani garam Di Desa Kusamba. Hasil penelitian ini menyatakan bahwa luas lahan berpengaruh positif dan signifikan terhadap pendapatan petani garam di Desa Kusamba . Hal ini berarti bahwa jika luas lahan pertanian meningkat atau semakin luas maka pendapatan akan meningkat. Hasil penelitian ini di dukung oleh Assis et al. (2014) yang meneliti luas lahan berpengaruh positif dan signifikan terhadap pendapatan petani nanas, mengungkap bahwa luas lahan merupakan satu - satunya faktor yang memiliki efek yang signifikan terhadap pendapatan bulanan pada petani, jadi jika luas lahan meningkat maka pendapatan petani akan meningkat, demikian juga sebaliknya.

Pengaruh langsung tenaga kerja terhadap pendapatan petani garam menunjukkan bahwa nilai standardized coefficient beta sebesar 0,184 dan nilai probabilitas sig. sebesar $0,003<0,05$ ini memiliki arti bahwa $\mathrm{H}_{0}$ ditolak dan $\mathrm{H}_{1}$ diterima, artinya tenaga kerja $\left(\mathrm{X}_{2}\right)$ berpengaruh positif dan signifikan terhadap pendapatan petani garam $\left(\mathrm{Y}_{2}\right)$. Hal ini berarti bahwa setiap peningkatan tenaga kerja sebesar 1 persen dengan harapan variabel lain konstan, maka akan menyebabkan peningkatan sebesar 0,184 persen pada pendapatan petani garam Di 
Desa Kusamba. Tenaga kerja merupakan faktor yang sangat penting dalam produksi, karena tenaga kerja merupakan faktor penggerak faktor input yang lain, tanpa adanya tenaga kerja maka faktor produksi lain tidak akan berarti. Dengan meningkatnya produktivitas tenaga kerja akan mendorong peningkatan produksi sehingga pendapatan pun akan ikut meningkat. Hasil penelitian ini didukung oleh I Putu Danendra Putra dan I Wayan Sudirman (2015) yang menyatakan bahwa secara parsial variabel tenaga kerja berpengaruh positif dan signifikan terhadap pendapatan pada usaha warung makan di Kecamatan Abiansemal.

Pengaruh langsung modal terhadap pendapatan petani garam menunjukkan bahwa nilai standardized coefficient beta sebesar 0,267 dan nilai sig. sebesar $0,014<0,05$ ini memiliki arti bahwa $\mathrm{H}_{0}$ ditolak dan $\mathrm{H}_{1}$ diterima, artinya modal $\left(\mathrm{X}_{3}\right)$ berpengaruh positif dan signifikan terhadap pendapatan petani garam $\left(\mathrm{Y}_{2}\right)$. Hal ini berarti bahwa setiap peningkatan modal sebesar 1 persen dengan harapan variabel lain konstan, maka akan menyebabkan peningkatan sebesar 0,267 persen pada pendapatan petani garam Di Desa Kusamba. Modal merupakan salah satu input atau faktor produksi yang dapat mempengaruhi pendapatan namun bukan satu-satunya faktor yang dapat meningkatkan pendapatan (Suparmoko, 2000). Ketersediaan modal dengan jumlah yang cukup dan berkesinambungan akan memperlancar produksi yang pada akhirnya akan meningkatkan produksi serta meningkatkan jumlah pendapatan usaha yang diperoleh oleh petani garam.

Hasil penelitian ini didukung oleh Hastina (2013) dalam penelitiannya yang berjudul Analisis Faktor Yang Mempengaruhi Pendapatan Pengusaha Pada Industri Kecil (Studi Kasus Pada Industri Marning Jagung, Kelurahan 
Pandanwangi, Kecamatan Blimbing, Kota Malang) bahwa modal pengusaha berpengaruh positif dan signifikan terhadap pendapatan pengusaha marning jagung. Pengaruh modal yang signifikan terhadap pendapatan sesuai dengan penelitian Setyaningsih Sri Utami dan Edi Wibowo (2013) dalam penelitiannya yang berjudul Pengaruh Modal Kerja Terhadap Pendapatan Dengan Lama Usaha Sebagai Variabel Moderasi (Survei Pada Pedagang Pasar Klithikan Notoharjo Surakarta) bahwa modal berpengaruh positif dan signifikan terhadap pendapatan pedagang di pasar Klithikan Notoharjo Surakarta.

Pengaruh langsung produksi garam terhadap pendapatan petani garam menunjukkan bahwa Nilai standardized coefficient beta sebesar 0,264 dan nilai sig. sebesar 0,003 $<0,05$ ini memiliki arti bahwa $\mathrm{H}_{0}$ ditolak dan $\mathrm{H}_{1}$ diterima, artinya produksi garam $\left(\mathrm{Y}_{1}\right)$ berpengaruh positif dan signifikan terhadap pendapatan petani garam $\left(\mathrm{Y}_{2}\right)$. Hal ini berarti bahwa setiap peningkatan produksi garam sebesar 1 persen dengan harapan variabel lain konstan, maka akan menyebabkan peningkatan sebesar 0,264 persen pada pendapatan petani garam Di Desa Kusamba.

Untuk mengetahui nilai $e_{1}$ yang menunjukkan jumlah varian variabel Produksi garam $\left(\mathrm{Y}_{1}\right)$ yang tidak dijelaskan oleh Luas lahan $\left(\mathrm{X}_{1}\right)$, Tenaga kerja $\left(\mathrm{X}_{2}\right)$, serta Modal $\left(\mathrm{X}_{3}\right)$, maka dapat dihitung dengan menggunakan rumus sebagai berikut.

$$
\begin{aligned}
e_{1} & =\sqrt{1-R 1^{2}} \\
& =\sqrt{1-0,795} \\
& =0,45
\end{aligned}
$$


Nilai kekeliruan standar $\mathrm{e}_{1}$ yang diperoleh sebesar 0,45 yang artinya 45 persen variansi produksi garam tidak dapat dijelaskan oleh luas lahan, tenaga kerja, dan modal.

Untuk mengetahui nilai $\mathrm{e}_{2}$ yang menunjukkan jumlah varian variabel Pendapatan Petani Garam di Desa Kusamba $\left(\mathrm{Y}_{2}\right)$ yang tidak dijelaskan oleh Luas lahan $\left(\mathrm{X}_{1}\right)$, Tenaga kerja $\left(\mathrm{X}_{2}\right)$, Modal $\left(\mathrm{X}_{3}\right)$, serta Produksi garam $\left(\mathrm{Y}_{1}\right)$, maka dapat dihitung dengan menggunakan rumus sebagai berikut.

$$
\begin{aligned}
e_{2} & =\sqrt{1-R 2^{2}} \\
& =\sqrt{1-0,918} \\
& =0,28
\end{aligned}
$$

Nilai kekeliruan standar $\mathrm{e}_{2}$ yang diperoleh sebesar 0,28 yang artinya 28 persen variansi pendapatan tidak dapat dijelaskan oleh luas lahan, tenaga kerja, modal, dan produksi garam.

Untuk memeriksa validitas model, terdapat indikator untuk melakukan pemeriksaan, yaitu koefisien determinasi total yang dihitung sebagai berikut:

$$
\begin{aligned}
\mathrm{R}_{\mathrm{m}}^{2} & =1-\left(\mathrm{e}_{1}\right)^{2}\left(\mathrm{e}_{2}\right)^{2} \\
& =1-(0,45)^{2}(0,28)^{2} \\
& =1-(0,20)(0,07) \\
& =1-(0,014) \\
& =0,98
\end{aligned}
$$

Berdasarkan hasil perhitungan koefisien determinasi total, maka diperoleh hasil sebesar 98 persen, yang memiliki arti bahwa variasi pendapatan petani garam di Desa Kusamba dipengaruhi oleh variasi luas lahan, tenaga kerja, modal, 
dan produksi garam, sedangkan sisanya yaitu sebesar 2 persen dipengaruhi oleh variabel lain yang tidak terdapat dalam model tersebut.

Penelitian ini menggunakan analisis jalur (path analysis) untuk menguji pola hubungan yang mengungkapkan pengaruh variabel atau seperangkat variabel terhadap variabel lainnya, baik pengaruh langsung maupun pengaruh tidak langsung. Berdasarkan hasil olah data dapat disusun model analisis jalur estimasi pada Gambar 2.

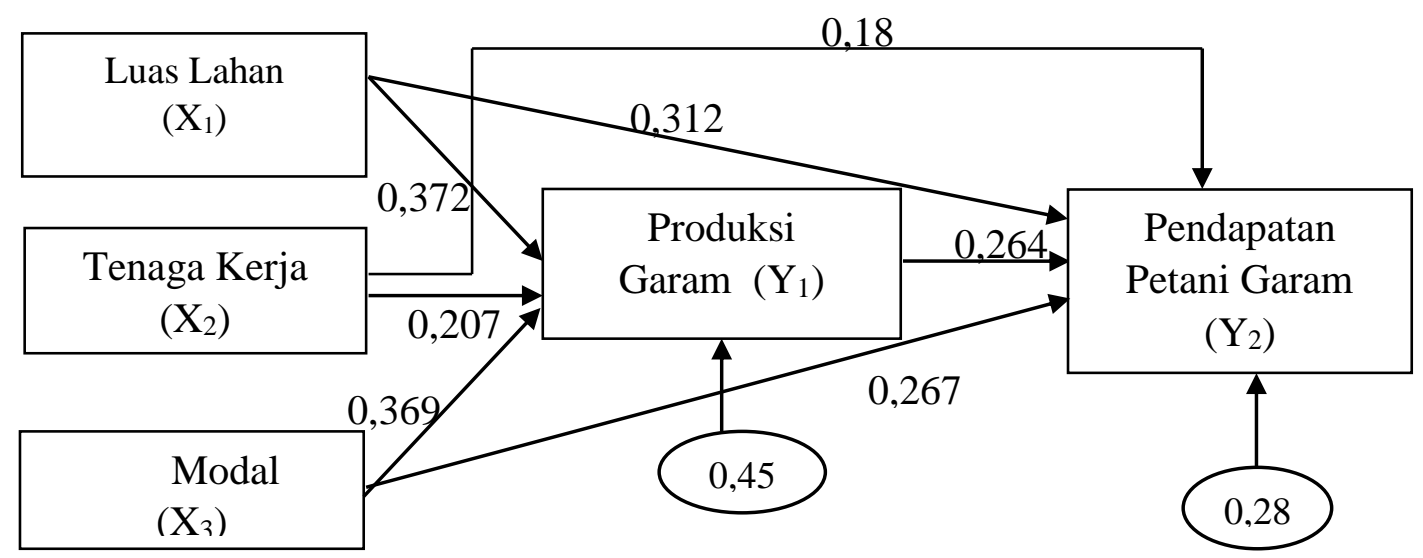

Gambar 2.

Diagram Hasil Analisis Jalur

Pengujian pengaruh tidak langsung luas lahan terhadap pendapatan petani garam melalui produksi garam menunjukkan bahwa $\mathrm{Z}$ hitung sebesar 2,08 > 1,96 artinya produksi garam $\left(\mathrm{Y}_{1}\right)$ merupakan variabel intervening dari luas lahan $\left(\mathrm{X}_{1}\right)$ terhadap pendapatan petani garam $\left(\mathrm{Y}_{2}\right)$ di Desa Kusamba, atau dengan kata lain luas lahan berpengaruh secara tidak langsung terhadap pendapatan petani garam melalui produksi garam. Hal ini menunjukkan bahwa ketika terjadi penambahan luas lahan maka tidak serta merta dapat berpengaruh terhadap pendapatan apabila tidak adanya peningkatan produksi. 
Pengujian pengaruh tidak langsung tenaga kerja terhadap pendapatan petani garam melalui produksi garam menunjukkan bahwa Z hitung sebesar 2,096 > 1,96 artinya produksi garam $\left(\mathrm{Y}_{1}\right)$ merupakan variabel intervening dari tenaga kerja $\left(\mathrm{X}_{2}\right)$ terhadap pendapatan petani garam $\left(\mathrm{Y}_{2}\right)$ di Desa Kusamba, atau dengan kata lain tenaga kerja berpengaruh secara tidak langsung terhadap pendapatan petani garam melalui produksi garam. Hal ini menunjukkan bahwa ketika terjadi penambahan jam kerja maka tidak serta merta dapat langsung berpengaruh terhadap pendapatan apabila tidak ada peningkatan produksi.

Pengujian pengaruh tidak langsung modal terhadap pendapatan petani garam melalui produksi garam $\mathrm{Z}$ hitung sebesar 2,080 >1,96 artinya produksi garam $\left(\mathrm{Y}_{1}\right)$ merupakan variabel intervening dari modal $\left(\mathrm{X}_{3}\right)$ terhadap pendapatan petani garam $\left(\mathrm{Y}_{2}\right)$ di Desa Kusamba, atau dengan kata lain modal berpengaruh secara tidak langsung terhadap pendapatan petani garam melalui produksi garam. Artinya, ketika terjadi penambahan modal tidak serta merta dapat langsung meningkatkan perolehan pendapatan apabila tidak terjadi peningkatan terhadap produksi. Adanya penambahan modal dapat meningkatkan petani untuk biaya pemeliharaan dan keperluan lain.

\section{SIMPULAN DAN SARAN}

Berdasarkan hasil analisis diatas, maka dapat ditarik simpulan sebagai berikut: 1). Luas lahan, tenaga kerja dan modal berpengaruh secara langsung terhadap produksi garam di Desa Kusamba Kecamatan Dawan Kabupaten Klungkung. 2). Luas lahan, tenaga kerja, modal dan produksi garam berpengaruh 
secara langsung terhadap pendapatan petani garam di Desa Kusamba Kecamatan Dawan Kabupaten Klungkung. 3). Luas lahan, tenaga kerja, dan modal berpengaruh secara tidak langsung terhadap pendapatan petani garam melalui produksi garam di Desa Kusamba Kecamatan Dawan Kabupaten Klungkung.

Berdasarkan hasil analisis dan kesimpulan diatas, maka dapat diajukan beberapa saran sebagai berikut : 1). Diharapkan agar para petani garam dapat memanfaatkan lahan yang dimiliki secara optimal, dan juga memanfaatkan segala faktor-faktor produksi yang dimilikinya. Selain itu, dapat menambah jam kerja dalam melakukan proses produksi garam yang nantinya akan meningkatkan hasil produksi sehingga dapat dipasarkan. Perlu peningkatan pemasaran dapat dilakukan di area yang ramai pengunjung lokal maupun wisatawan. 2). Kepada Pemerintah dapat memberi perhatian khusus kepada para petani garam dengan membantu modal untuk upaya pengembangan garam itu tersendiri. Misalnya pemberian bantuan berupa barang yang dapat digunakan untuk melakukan proses produksi garam. Dengan demikian, biaya produksi yang dikeluarkan oleh para petani garam akan lebih berkurang sehingga dapat meningkatkan pendapatan petani garam itu tersendiri.

\section{REFERENSI}

Agustarita Vita \& Wayan Sudirman. 2015. Pengaruh Produksi, Jumlah Penduduk, PDB dan Kurs Dolar Terhadap Impor Jagung Di Indonesia. E-Jurnal Ekonomi Pembangunan Universitan Udayana, 4(2): pp:71-79.

Antara, Made \& Yono Wirawan. 2013. Permintaan Buah Pisang Ambon Oleh Rumah Tangga Di Kecamatan Denpasar Barat, Kota Denpasar, Provinsi Bali. Jurnal Ekonomi Kuantitatif Terapan, 6(1):pp:16-29. 
Al-Haboby, Azhr, Breisinger, Clemens, Debowicz, Dario, El Hakim, Abdul Hussein, Ferguson, Jenna, Telleria, Roberto, Van Rheenen, Teunis. 2016. The Role of Agriculture for Economic Devolepment and Gender In Iraq a Computable General Equilibrium Model Approach. Journal of Devoloping Area, 50(2): pp:1653-1657

Ardika,I Wayan, Gede Sujana Budhiasa. 2017. Analisis Tingkat Kesehjateraan Petani Di Desa Bangli Kecamatan Baturiti Kabupaten Tabanan.Piramida, 13(2) :pp:87-96.

Assis, K., Nurrul Azzah, Z \& Mohammad Amizi. 2014. Relationship Between Socioeconomic Factors, Income And Productivity Of Farmers : A Case Study On Pineapple Farmers. International Journal of Research in Humanities, Arts and Literature, 1(2):pp:67-78.

Berihun Kassa Hailu dan Bihon Kassa Abrha. 2014. Adoption and Impact of Agricultural Technologies on Farm Income: Evidence From Southern Tigray, Northern Ethiopia. International Journal of Food and Agricultural Economics, 2(3): pp: 91-106.

Cahya Ningsih, Ni Made, I Gusti Bagus Indrajaya. 2015. Pengaruh Modal Dan Tingkat Upah Terhadap Nilai Produksi Serta Penyerapan Tenaga Kerja Pada Industri Kerajinan Perak. Jurnal Ekonomi Kuantitatif Terapan, 8(1):pp:60661

Dharma Saputra, I Made Alit \& I Wayan Wenagama. 2019. Analisis Efisiensi Faktor Produksi Usaha Tani Cabai Merah di Desa Buahan, Kecamatan Payangan, Kabupaten Gianyar. E-Jurnal Ekonomi Pembangunan Universitan Udayana, 8(1):pp:31-60.

Gathogo, George and Mary Ragui. 2014. Efects Of Capital and Technology on The Performance of SMEs in Manufacturing Sector in Kenya-Case o Selected firms in Thika Municipality. European Journal of Bussiness and Management, 6(7): pp:308-31.

Glock, Christoph H. 2011. Batch sizing with controllable production rates in a multi-stage production system. International Journal of Production Research,49(20):pp:6017-6039.

Godby, Robert, et al., 2015. The Impact of the Coal Economy on Wyoming.The Journal of Economic and Fublic Policy. 2(2): pp: 234-254.

Gouse, Marnus, Jenifer Piesse, and Colin Thirtle. 2006. Output and Labour Effects of GM Maize and Minimum Tillage in a Communal Area of KwaZuluNatal. Journal of Development Perspectives,2(2):pp:192-207. 
Hae-Young Lee, Jongsung Kim and Beom Cheol Cin. 2013. Empirical Analysis on the Determinants of Income Inequality in Korea. International Journal of Advanced Science and Technology, 53:pp: 95-110.

Izzaty dan Sony Hendra Pramana. 2011. Kebijakan Pengembangan Produksi Garam Nasional. E-Jurnal Ekonomi dan Kebijakan Publik, 2(2): pp:654.

Jelocknic, Marko, Subic, Jonel, Nastic, Lana. 2011. Analisysis Of Agriculture And Rular Development In The Upper Danbe Region-Swot Analysis. Journal International Agricultural Economics, 3(2):pp:1-10.

Kasryno. 2000. Sumberdaya Manusia dan Pengolahan Lahan Pertanian Pedesaan Indonesia. Jurnal FAF,18(2):pp:1-13.

Maharani Putri, Ni Made Dwi,I Made Jember. 2016. Modal Sendiri dan Lokasi Usaha Terhadap Pendapatan Usaha Mikro Kecil Menengah (UMKM) di Kabupaten Tabanan (Modal Pinjaman sebagai Variabel Intervening). Jurnal Ekonomi Kuantitatif Terapan, 9(2):pp:142-150.

Mawazo M. Magesa, Kisangiri Michael and Jesuk Ko. 2014. Access to Agricultural Market Information by Rural Farmers in Tanzania. International Journal of Information and Communication Technology Research. 4(7): pp: 264-273.

Mubyarto. 1989. Pengantar Ekonomi Pertanian. Jakarta: LP3ES.

Ng'ombe, John, Thomson Kalinda, Gelson Tembo and Elias Kuntashula. 2014. Econometric Analysis of the Factors that Effect Adoption of Conservation Farming Practices by Smallholder Farmers in Zambia. Journal of Sustainable Development, 7(4),pp: 124-138.

Parinduri, Rasyad A. 2014, Family Hardship And The Growth Of Micro And Small Firms In Indonesia, Bulletin of Indonesian Economic Studies, 50(1):pp:53-73.

Todaro, Michael P. and Stephen C. Smith.(2006). Pembangunan Ekonomi. Edisi Kesembilan. Jakarta: Penerbit Erlangga.

Tri Astari, Ni Nyoman, dan Nyoman Djinar Setiawina. 2016. Pengaruh Luas Lahan, Tenaga Kerja, da Pelatihan Melalui Produksi Sebagai Variabel Intervening Terhadap Pendapatan Petani Asparagus di Desa Pelaga Kecamatan Petang Kabupaten Badung. E-Jurnal Ekonomi dan Bisnis Universitas Udayana, 5 (7):pp:2211-2230.

Sharma, G.S Bangarva, and Y.K Sharma. 2007. Factors Affecting Gross and Net Income of Farmers in Different Farming Systems. Indian Res. J, 7 (1):5256. 